\title{
Retraction Note: Mir-655 up-regulation suppresses cell invasion by targeting pituitary tumor-transforming gene- 1 in esophageal squamous cell carcinoma
}

\author{
Yuanyuan Wang ${ }^{1}$, Wenqiao Zang ${ }^{1}$, Yuwen Du${ }^{1}$, Yunyun $\mathrm{Ma}^{1}$, Min $\mathrm{Li}^{1}$, Ping Li ${ }^{2}$, Xudong Chen ${ }^{3}$, Tao Wang ${ }^{4}$, \\ Ziming Dong ${ }^{1}$ and Guoqiang Zhao ${ }^{1 *}$
}

\section{Retraction Note: J Transl Med (2013) 11:301 \\ https://doi.org/10.1186/1479-5876-11-301}

The Editor-in-Chief has retracted this article [1] because Figure 3a overlaps with Figure 2 in [2]. An investigation by Zhengzhou University has confirmed this. The data reported in this article are therefore unreliable. There is also considerable text overlap with a previously published article [3]. Guoqiang Zhao does not agree with this retraction. The other authors have not responded to correspondence from the editor about this retraction.

\footnotetext{
Author details

${ }^{1}$ College of Basic Medical Sciences, Zhengzhou University, No.100 Kexue Road, Zhengzhou 450001, Henan, China. ${ }^{2}$ Department of Respiratory Medicine, The First Affiliated Hospital of Zhengzhou University, Zhengzhou 450052, Henan, China. ${ }^{3}$ Department of Histology and Embryology, Luohe Medical College, Luohe 462002, Henan, China. ${ }^{4}$ Department of Hemato-tumor, The First Affiliated Hospital of Henan University of TCM, Zhengzhou 450000, Henan, China.
}

Published online: 17 February 2020
References

1. Wang Y, Zang W, Du Y, Ma Y, Li M, Li P, Chen X, Wang T, Dong Z, Zhao G. Mir-655 up-regulation suppresses cell invasion by targeting pituitary tumor-transforming gene- 1 in esophageal squamous cell carcinoma. J Transl Med. 2013;11:301. https://doi.org/10.1186/1479-5876-11-301.

2. Zang W, Wang T, Wang Y, Li M, Xuan X, Ma Y, Du Y, Liu K, Dong Z, Zhao G. Myricetin exerts anti-proliferative, anti-invasive, and pro-apoptotic effects on esophageal carcinoma EC9706 and KYSE30 cells via RSK2. Tumor Biol. 2014:35:12583. https://doi.org/10.1007/s13277-014-2579-4.

3. Wang Y, Li M, Zang W, Ma Y, Wang N, Li P, Wang T, Zhao G. MiR-429 upregulation induces apoptosis and suppresses invasion by targeting $\mathrm{BCl}-2$ and SP-1 in esophageal carcinoma. Cell Oncol. 2013;36:385. https://doi. org/10.1007/s13402-013-0144-6.

\section{Publisher's Note}

Springer Nature remains neutral with regard to jurisdictional claims in published maps and institutional affiliations.

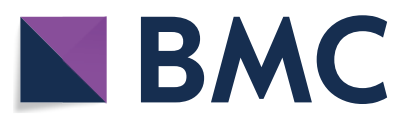

(c) The Author(s) 2020. This article is licensed under a Creative Commons Attribution 4.0 International License, which permits use, sharing, adaptation, distribution and reproduction in any medium or format, as long as you give appropriate credit to the original author(s) and the source, provide a link to the Creative Commons licence, and indicate if changes were made. The images or other third party material in this article are included in the article's Creative Commons licence, unless indicated otherwise in a credit line to the material. If material is not included in the article's Creative Commons licence and your intended use is not permitted by statutory regulation or exceeds the permitted use, you will need to obtain permission directly from the copyright holder. To view a copy of this licence, visit http://creativecommons.org/licenses/by/4.0/. The Creative Commons Public Domain Dedication waiver (http://creativecommons.org/publicdomain/zero/1.0/) applies to the data made available in this article, unless otherwise stated in a credit line to the data. 